\title{
Penganiayaan Emosional Anak Usia Dini melalui Bahasa Negatif dalam Kekerasan Verbal
}

\author{
Nurmalinaa $^{1 凶}$, Yolanda Pahrul $^{1}$ \\ Pendidikan Guru Pendidikan Anak Usia Dini, Universitas Pahlawan Tuanku Tambusai ${ }^{(1)}$ \\ DOI: $10.31004 /$ obsesi.v5i2.909
}

\begin{abstract}
Abstrak
Orangtua sering meluapkan emosi akibat tingkah laku anaknya yang tidak sesuai dengan kehendaknya dalam bentuk kekerasan verbal. Penelitian ini bertujuan untuk mendapatkan solusi untuk mencegah dan mengatasi masalah kekerasan berbahasa pada anak usia dini. Metode penelitian ini adalah penelitian library research. Teknik pengumpulan data dengan mendokumentasikan artikel, buku, dan analisis lapangan. Selanjutnya mengumpulkan bahan-bahan yang dibutuhkan, pengelompokan, dan kemudian dianalisis sesuai dengan tujuan penelitian. Dari Hasil penelitian diketahui ada dua faktor dominan alasan orang tua untuk melakukan kekerasan verbal yaitu pengalaman dan pengetahuan orang tua. Dampak yang ditimbulkan adalah anak akan menjadi manusia yang tidak berakhlak, baik dari segi perbuatan maupun ucapan. Upaya pencegahan yang dapat dilakukan adalah dengan memositifkan bahasa dalam berkomunikasi terhadap anak.
\end{abstract}

Kata Kunci: penganiayaan emosional; anak usia dini, bahasa, kekerasan verbal

\begin{abstract}
Parents often express emotions due to their children's behavior that is not according to their wishes in the form of verbal abuse. This study aims to find solutions to prevent and overcome the problem of verbal violence in early childhood. This research method is library research research. Data collection techniques by documenting articles, books, and field analysis. Furthermore, collecting the materials needed, grouping, and then analyzed according to research objectives The results showed that there were two dominant factors that influenced parents to engage in verbal violence, namely parental knowledge and experience. The impact is that the child will become immoral, both in terms of deeds and words. Prevention efforts that can be done are to positivate language in communicating with children.
\end{abstract}

Keywords: emotional abuse, early childhood, language, verbal abuse

Copyright (c) 2020 Nurmalina

$\triangle$ Corresponding author :

Email Address : nurmalina18des@gmail.com (Bangkinang, Riau, Indonesia)

Received 14 November 2020, Accepted 5 December 2020, Published 19 December 2020 


\section{PENDAHULUAN}

Bahasa memegang peranan penting dalam kehidupan manusia. Manusia dalam menghadapi masalah membutuhkan sesamanya dalam memecahkan masalah sehingga terjalin kerjasama dalam menghadapi persoalan. Hal yang dapat membantu dalam menjalin kerjasama ialah bahasa (Winarni et al., 2018). Pengetahuan manusia dapat berkembang jika manusia memiliki bahasa yang mampu mengkomunikasikan informasi dan jalan pikiran yang melatar belakangi informasi tersebut (Bakhtiar, 2014). Disamping itu, karakter setiap individu dapat dikenali melalui bahasa yang digunakan. Sebab, Bahasa adalah tanda yang jelas dari kepribadian baik dan buruk pengguna (Riniwati, 2015).

Nurjamal et al. (2011) menyatakan bahwa seseorang dengan bahasa yang baik pasti akan mendapatkan apresiasi yang baik dan pengakuan sosial yang positif terhadap lingkungannya. Jika lingkungan keluarga dan lingkungan masyarakat tidak mendukung atau mendukung perkembangan mental dan penguasaan bahasa anak, maka akan menjadi ciri dari metode bahasa anak, baik atau buruk. Dasar pembentukan moral anak juga membutuhkan bahasa sebagai media atau alat untuk menyampaikan pesan-pesan moril. Dalam hal berbahasa, ajaran Islam memberi penekanan pada nilai sosial, religius, dan budaya. Sebagaimana diisyaratkan dalam ayat berikut, yang artinya:

“... dan lunakkanlah suaramu, sesungguhnya seburuk-buruk suara adalah suara himar." (QS. Lukman: 19)

Masa balita merupakan masa emas tumbuh kembang anak. Masa di mana rasa ingin tahu anak sangat besar untuk mengeksplorasi apa pun yang baru dilihatnya. Namun, perkembangan anak sering kali sering terhambat tanpa didasari oleh orangtuanya. Orangtua sering meluapkan emosi karena tingkah laku anaknya yang tidak sesuai dengan kehendaknya. Orang tua menganggap wajar untuk memarahi anaknya yang terkadang sedikit kasar dengan maksud agar anak bisa diurus, patuh dan penurut (Mysa \& Fithria, 2016). Banyak orang tua tanpa sadar menggunakan bahasa negatif pada anak-anak mereka, yang memanifestasikan dirinya dalam bentuk pelecehan verbal. Padahal, perlakuan dan penggunaan bahasa positif dan negatif yang diperoleh anak akan sangat mempengaruhi pembentukan karakter dan kesehatan mental anak (Zuhrudin, 2017).

Bahasa negatif memiliki ciri yang berbeda-beda, yaitu: (1) mengatakan hal-hal yang tidak boleh dilakukan, (2) berpura-pura menuduh, (3) menggunakan kata-kata negatif seperti: Saya tidak bisa, tidak mau, tidak, malas, dll., dan (4) menekankan tindakan negatif. Sebagai orang tua, jika anak mulai berbicara, orang tua sering kali menggunakan kekerasan verbal dengan mengucapkan kata-kata negatif, seperti "kamu bodoh", "kamu banyak bicara" dan "kamu kasar". Anak-anak akan mengingat semua pelecehan verbal jika semua pelecehan verbal berlangsung selama suatu periode (Fitriana et al., 2015). Kekerasan verbal seperti itu adalah pelecehan emosional berkelanjutan terhadap anak-anak yang dapat berdampak negatif pada perkembangan anak (Armiyanti et al., 2017). Ketika anak mengalami kekerasan verbal dalam kondisi ini, anak akan merasa tidak mampu dan tidak dapat menciptakan keinginan untuk tumbuh (Siregar, 2017).

Seseorang yang dicap negatif membuat dirinya tidak dapat berkembang dengan baik, menimbulkan ketegangan, dan dianggap lemah karena merasa malu dengan apa yang dipersepsikan orang tentang dirinya. Bagi anak-anak yang dicap negatif, tentunya hal ini menjadi pemahaman baru, bahwa mereka dipandang lemah dan tidak mampu berbuat apaapa. Bahkan, hal ini akan berdampak dan dirasakan oleh anak hingga akhir masa remaja (Mustillo et al., 2013).

Kekerasan verbal terhadap anak akan menimbulkan kesusahan yang akan membuat anak berpikir seperti yang dikatakan orang tuanya (Armiyanti et al., 2017). Ahli Klinis Hipnoterapis Dra. MTh. Widya Saraswati mengungkapkan bahwa perkataan orang tua dapat diserap langsung oleh alam bawah sadar anak yang dapat membuat anak menampilkan diri seperti yang diucapkan oleh orangtuanya. Ketika seseorang dianggap menyimpang, maka ia 
cenderung berperilaku menyimpang. Label divergen yang diberikan oleh orang lain akan mempengaruhi konsep diri orang tersebut dan perilaku orang tersebut sejalan dengan apa yang orang lain katakan (Strub et al., 1979). Dengan cap yang ditempelkan pada seseorang, itu (juga dikenal sebagai proses reorganisasi psikologis) dan mungkin menghasilkan karier yang menyimpang (Narwoko \& Suyanto, 2006).

Penganiayaan emosional melalui pelecehan verbal kepada seorang anak akan menyebabkan tekanan emosional (Mahmud, 2019). Anak akan mendapatkan perkembangan buruk, hubungan sosial yang bermasalah, membuat anak menjadi lebih agresif, dan orang dewasa menjadi musuh. Menurut UNICEF (United for Children) tahun 2016, 80\% anak usia 2 hingga 14 tahun pernah mengalami kekerasan fisik maupun mental, 62\% kekerasan terjadi di lingkungannya (keluarga dan sekolah), sisanya 38\% di publik (Fitriana et al., 2015). Parahnya lagi, di Indonesia di tahun-tahun sebelumnya, ketua Komnas PA menyatakan bahwa secara psikis, hampir 90 persen anak Indonesia mengalaminya sebagai teriakan dan penghinaan dan hampir semua anak Indonesia mengalami kekerasan verbal. Hal itu seolah-olah dianggap bukan lagi kekerasan dalam lingkup sosial budaya di Indonesia.

Hasil penelitian Zahara Farhan (2018) menunjukkan bahwa terdapat 5 faktor yang membuat orang tua melecehkan anak. Pertama, faktor pengetahuan orang tua tidak mengetahui bahwa kekerasan verbal lebih berbahaya daripada kekerasan psikologis, kedua, faktor pengalaman orang tua memiliki pengalaman yang sama, sehingga cenderung meniru kekerasan psikologis., ketiga, dukungan keluarga terhadap anak dengan kelainan fisik maupun anak lahir yang tidak diharapkan. Keempat, faktor ekonomi karena kemiskinan ataupun pengangguran, dan kelima, faktor lingkungan orang tua menjadi kaku dalam hal mendidik anak. Karakter orang tua juga menjadi salah satu penyebab terjadinya kekerasan verbal pada anak (Putri \& Santoso, 2012).

Perkembangan superego anak biasanya pada saat berusia 3 sampai 6 tahun. Pada masa ini, anak dianggap sangat kritis untuk perkembangan emosi dan psikologisnya. Padahal, di usia ini anak-anak lebih aktif dan berpenampilan nakal. Kenakalan anak usia 3 sampai 6 tahun merupakan hal yang wajar, dengan cara ini anak belajar lingkungan dengan cara yang kreatif, namun terkadang orang tua melihatnya sebagai sesuatu yang mengganggu, dan orang tua tidak segan-segan menggunakan kekerasan verbal seperti berteriak dan mengabaikan anak itu

Perkembangan superego anak biasanya antara usia 3 dan 6 tahun. di masa ini, anak sangat kritis terhadap perkembangan emosi dan psikologisnya. Bahkan, di usia ini anak-anak lebih aktif dan terlihat nakal. Kenakalan anak usia 3 - 6 tahun merupakan hal wajar, sehingga anak belajar di lingkungan dengan cara yang kreatif, namun terkadang orang tua melihatnya sebagai sesuatu yang mengganggu, dan orang tua tidak segan-segan menggunakan kekerasan verbal seperti berteriak dan mengabaikan anak (Wong, 2008). Penelitian ini bertujuan untuk menganalis dan mengetahui faktor paling dominan yang melatarbelakangi terjadinya penganiayaan emosial melaui bahasa negatif dalam kekerasan verbal, dampak yang ditimbulkan, serta solusi yang ditawarkan untuk mencegah dan mengatasi masalah tersebut.

\section{METODOLOGI}

Metode penelitian ini adalah penelitian pustaka (library research) yaitu penelitian pustaka dengan data yang diperoleh dari perpustakaan, seperti: ensiklopedia, skripsi, skripsi, disertasi, buku, jurnal, dokumen, kamus dan majalah (Khahtibah, 2013). Langkahnya dimulai dengan mengumpulkan bahan-bahan yang dibutuhkan, menyusunnya, kemudian menganalisisnya sesuai dengan tujuan penelitian. Pelaksanaan penelusuran pustaka dalam penelitian ini adalah pemilihan topik, guna mencari informasi tentang topik tersebut dalam bentuk artikel dan penelitian serupa. Sumber data penelitian yang diperoleh dari kepustakaan memiliki variabel sesuai dengan topik penelitian. Metode pengumpulan data dalam penelitian ini adalah dokumentasi, yang mencari data variabel-variabel dalam bentuk artikel dan penelitian. 


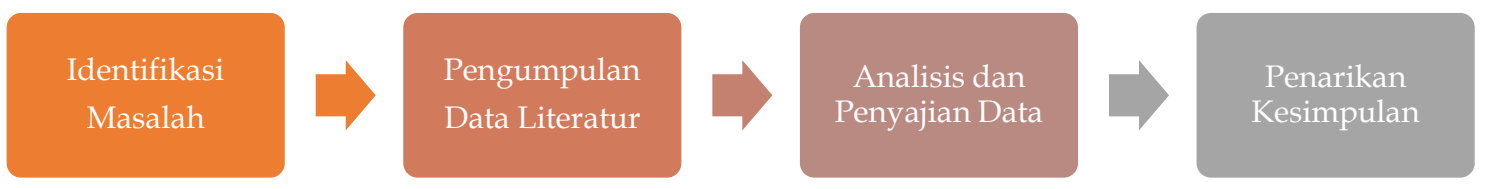

Gambar 1. Desain Penelitian

\section{HASIL DAN PEMBAHASAN}

Faktor Dominan yang Penganiayaan Emosial Melaui Bahasa Negatif dalam Kekerasaan Verbal pada AUD

Hasil Penelitian (Putri \& Santoso, 2012) menunjukkan bahwa orang tua menganggap anak-anak mereka yang berusia antara 3 dan 4 tahun sebagai anak yang sewenang-wenang, sehingga menjadi alasan melakukan kekerasan verbal yang tidak mereka sadari sebagai penganiayaan emosional terhadap anak-anak mereka. Di satu sisi, banyak juga orang tua dan pendidik PAUD yang tidak mampu membedakan antara anak hiperaktif dan anak nakal, sehingga sangat mungkin penanganan yang salah (Widiharto et al., 2012). Orang tua yang berkarakter keras cenderung lebih sering melakukan kekerasan verbal terhadap anak. Karakter ini dipengaruhi dengan latar belakang keluarganya. Inilah penyebab terjadinya rangkaian kekerasan dalam rumah tangga.

Soetjiningsih (2014) menyatakan bahwa faktor yang bisa menyebabkan orang tua yang berkepribadian tangguh cenderung akan lebih menggunakan pelecehan verbal kepada anak. Kepribadian ini dilatarbelakangi oleh keluarga di masa lalu. Inilah penyebab terjadinya rangkaian kekerasan dalam keluarga. Hal ini bertolak belakang dengan hasil penelitian Fitriana et al. (2015) yang meneliti faktor perilaku orang tua dalam penyalahgunaan verbal terhadap AUD. Hasil penelitian ini memaparkan bahwa tidak ada korelasi antara faktor pendidikan dan penghasilan orang tua dengan terjadinya kekerasan verbal pada anak prasekolah, melainkan dipengaruhi oleh usia, kecerdasan, attitude, kedewasaan, dan faktor sekitarnya. Pengalaman orang tua yang diasuh secara baik akan mengasuh anaknya dengan baik pula. Orang tua yang memiliki pengalaman pengasuhan yang baik melakukan hal yang sama kepada anak-anak mereka. Di sisi lain, orang tua yang memiliki pengalaman pengasuhan yang tidak baik lebih cenderung melakukan penganiayaan verbal kepada anakanaknya.

Hasil penelitian Farhan (2019) menunjukkan bahwa terdapat 5 Faktor penyebab orang tua menggunakan penganiayaan verbal terhadap anak. Pertama, faktor pengetahuan orang tua tidak mengetahui bahwa penganiayaan verbal lebih berbahaya daripada kekerasan psikologis. Kedua, faktor pengalaman orang tua memiliki pengalaman yang sama sehingga cenderung untuk meniru. Ketiga, dukungan keluarga terhadap anak dengan kelainan fisik maupun anak lahir yang tidak diharapkan. Keempat, faktor ekonomi karena kemiskinan ataupun pengangguran, dan kelima, faktor lingkungan orang tua menjadi kaku dalam hal mendidik anak. Berbeda dengan penelitian yang dilakukan oleh Putri \& Santoso (2012), diketahui bahwa orang tua telah memahami bahwa tindakan verbal adalah perilaku kekerasan. Namun demikian, penganiayaan verbal tetap dilakukan oleh orang tua karena mereka sangat menyayangi anaknya, yaitu sampai anak mereka menyadari bahwa apa yang mereka lakukan itu salah. Disamping itu, Zuhrudin (2017) menemukan juga bahwa tidak ada korelasi antara penghasilan dan perilaku orang tua terhadap penganiayaan verbal pada anak usia dini. Namun, pengalaman orang tua berpengaruh signifikan terhadap sikap orang tua untuk melakukan penganiayaan verbal terhadap anak usia dini. Orang tua yang mendapatkan pengalaman yang baik akan memiliki perilaku yang tidak cenderung melecehkan anaknya secara verbal. Namun di sisi lain, orang tua yang memiliki pengalaman tidak baik akan cenderung menciptakan penganiayaan verbal terhadap anak mereka. 
Hasil penelitian Vega et al. (2019) menemukan bahwa yang lebih sering melakukan kekerasan verbal terhadap anak adalah ibu mereka. Kasus kekerasan verbal yang dilakukan ibu dengan emosi yang bagus dapat terjadi karena penggunaan koping yang tidak memadai yang pakai ibu untuk menyelesaikan masalah. Tata cara koping tersebut berupa tata cara koping, yaitu penekanan terhadap perasaan bawah sadar pada pikiran, impuls yang tidak menyenangkan atau saling berbeda satu sama lain yang pernah terjadi. Pengalaman ini begitu kuat direkam oleh ibu sehingga ketika hal yang sama terjadi lagi, ibu akan melakukan hal yang sama seperti yang pernah dilaluinya, seperti ungkapan perasaan dalam ungkapan verbal.

Berdasarkan paparan di atas, diketahui faktor dominan orangtua yang melakukan kekerasan verbal terhadap anaknya adalah faktor pengetahuan orangtua dan pengalaman orangtua. Orangtua yang melakukan penganiayaan emosional tidak mengetahui bahwa kekerasan verbal memiliki dampak yang sangat buruk, bahkan bahaya daripada kekerasan fisik. Pengalaman orang tua berpengaruh kuat pada perilaku merela ketika melakukan penganiayaan verbal pada anak usia dini. Orang tua yang pernah mengalami pengasuhan yang buruk cenderung melecehkan anak-anak mereka secara verbal. Sejalan dengan hasil penelitian Zuhrudin (2017), dipahami bahwa pengalaman orang tua berpengaruh kuat pada sikap orang tua ketika melakukan penganiayaan verbal pada anak usia dini.

Perilaku orang tua dalam kekerasan verbal terhadap anak usia dini disebabkan oleh mentalitas mereka yang beranggapan bahwa anak tidak tahu apa pun. Dengan begitu, orangtua pun merasa pola asuh bagaimanapun bisa dilakukannya terhadap anak (Lestary, 2016). Anehnya lagi, meskipun orang tua biasanya tidak setuju pada penganiayaan verbal, namun pada lain aspek orang tua tetap pernah melakukan kekerasan verbal pada anak mereka (Erniwati \& Fitriani, 2020). Hal tersebut dengan dalih sebagai bentuk kasih sayang dan niat baik kepada anaknya, artinya anak tersebut meyakini bahwa apa yang dilakukannya itu salah. Orang tua percaya jika penganiayaan adalah satu-satunya solusi ketika membesarkan dan mengajari anak (Kadir \& Handayaningsih, 2020).

Orangtua adalah pendidikan utama dan contoh bagi anaknya, terutama dalam berbahasa. Untuk itu, orang tua harus juga menjadi manusia yang baik untuk menciptakan anak yang baik pula (Kadir \& Handayaningsih, 2020). Menjadi orang tua yang baik butuh ilmu, harus mencari sendiri dengan membaca buku, mengikuti parenting class dan lain sebagainya. Dengan demikian, tentunya dapat memutuskan tradisi dan pengalaman orangtua dalam pola asuh yang buruk, demi masa depan anak yang lebih baik. Orangtua juga harus memiliki kesadaran akan aturan berbahasa (Awarness Of the Norm), sehingga dapat memacu pemakaian bahasa secara teliti, benar, santun, dan cermat dalam berkomunikasi dengan anaknya. Kesadaran ini adalah faktor penentu perilaku tutur dalam wujud penggunaan bahasa. Jika tidak, penganiayaan emosional melalui bahasa negatif dalam kekerasan verbal akan akan dapat menghancurkan masa depan anak. Psikolog Fajri (2019), dalam Harian Media Indonesia online, mengatakan bahwa kekerasan verbal lebih buruk daripada kekerasan fisik, yang memerlukan masa penyembuhan yang panjang melalui pengobatan dan bimbingan, dikarenakan sifatnya yang abstrak.

\section{Dampak Penganiayaan Emosial Melaui Bahasa Negatif dalam Kekerasaan Verbal pada AUD}

Kekerasan verbal yang dialami pada masa anak-anak sedikit banyaknya akan membawa dampak dalam kehidupan anak tersebut. Lestary (2016) menyatakan bahwa akibat pelecehan verbal, anak lebih agresif, seperti komunikasi dengan dampak negatif pada perkembangan otak mereka, mereka akan tetap berada pada situasi yang mengancam dan membuat lebih sulit untuk berpikir selama ini bahwa situasi yang muncul hanya berdasarkan naluri tanpa pertimbangan terlebih dahulu. Anak akan agresif dan ketika mereka menjadi orang tua juga akan memiliki kepribadian seperti orang tua mereka (Munawati, 2011). Selain 
itu, Hal ini juga berdampak pada psikologis yang bisa menjadikan anak tidak peka dengan perasaan orang lain (Soetjiningsih, 2014).

Penganiayaan verbal akan menciptakan efek jangka panjang yaitu menciptakan rentetan penganiayaan dalam keluarga. Temuan ini sejalan pada temuan penelitian Munawati, temuan jangka panjang lainnya ketika anak yang mengalami penganiayaan verbal nantinya bisa melakukan hal yang serupa pada saat menjadi orang tua. Ini terjadi karena bayi pada dasarnya adalah peniru (Munawati, 2011).

Tingkat pelecehan atau kekerasan mempengaruhi tingkat keparahan anak dan umur anak (Irwanto, 1997). Selama masa anak-anak, keterikatan terhadap orang tua atau perawat erat. Ketergantungan anak-anak sangat kuat pada mereka. Pada masa itu, keterikatan adalah hubungan emosional yang diciptakan anak melalui interaksinya dengan orang-orang yang memiliki makna tersendiri dalam hidup mereka, yaitu orang tua. (Neil J. Salkind, 2002). Jika orang tua seharusnya protektif, tetapi menciptakan ketidaknyamanan, hal ini dapat menimbulkan rasa terancam, ditolak, juga tidak berharga (Tarabulsy et al., 2008).

Dampak penganiayaan emosional yang dilakukan oleh orangtua dalam kekerasan verbal terhadap anak memiliki dampak yang tinggi sehingga dapat menyebabkan perilaku yang buruk (Wulandari \& Nurwati, 2018). Dengan demikian, anak yang menjadi korban penganiayaan emosional akan menjadi manusia yang tidak berakhlak, baik dari segi perbuatan maupun ucapan. Anak tersebut akan dengan mudahnya menggunakan bahasabahasa yang negatif dalam kehidupan sosialnya dan melakukan tindakan-tindakan yang menyimpang. Anak juga dapat besar menjadi karakter yang tidak peduli pada sekitar. Mereka akan susah bergaul dan cenderung lebih tertutup.

Penyebab terhambatnya pembentukan karakter anak sebagian besar terjadi karena adanya kekerasan verbal (Wibowo \& Parancika, 2020). Anak yang mendapatkan penganiayaan verbal akan mengalami masalah ketika hidup selama masa kanak-kanak dan pada tahap kehidupan berikutnya. Efek kekerasan verbal pada anak yang pernah merasakan antara lain: merasa dikurung, ketakutan, anak akan kewalahan oleh kesedihan, kurang percaya diri, dan anak menjadi agresif (Nurwijayanti \& Iqomh, 2019), ketidakpekaan terhadap perasaan orang lain, munculnya gangguan kepribadian antisosial atau kepribadian antisosial, motivasi belajar rendah, bunuh diri yang paling parah (Lestary, 2016).

Jika seorang anak mengalami cara orang tuanya mengekspresikan kemarahan melalui sikap agresif, seperti pelecehan dan kekerasan, kemungkinan besar anak tersebut akan melakukan hal yang serupa saat mengungkapkan kemarahan karena mereka telah mempelajari perilaku tersebut. Anak sejak dini akan terbiasa hingga dewasanya melakukan penganiayan emosional. Penganiayaan emosional menyebabkan kenakalan dalam bentuk perilaku jahat atau nakal yang dilakukan oleh anak sehingga mengganggu diri sendiri dan orang lain (Alfianur et al., 2020). Ketika sudah masuk dunia sekolah, maka ia akan menjadi anak yang suka tindakan 'bullying', mengganggu orang lain, bahkan sampai berbuat tawuran. Tawuran yang dilakukan anak sudah masuk pada kategori kriminalitas, karena mengakibatkan adanya korban luka dan korban cacat permanen.

\section{Upaya Pencegahan dan Mengatasi Penganiayaan Emosial dalam Kekerasaan Verbal pada Anak Usia Dini}

Upaya pencegahan dan mengatasi penganiayaan emosial dalam Kekerasaan Verbal pada AUD adalah dengan mempositifkan bahasa dalam berkomunikasi terhadap anak. Hasil penelitian Saudah (2014) menunjukkan bahwa pengaruh penggunaan bahasa positif terhadap pendidikan moral: 1) Tampak pada hasil tes awal 46\%, dan setelah pembelajaran dengan bahasa positif, hasil post-tes meningkat menjadi $54 \%$, yaitu ada perkembangan $8 \%$ 2) Hal tersebut berdampak pada pola berpikir positif dan perilaku positif anak. Respon positif ditunjukkan oleh siswa yang toleran terhadap teman, percaya diri, kemampuan untuk bekerja sama (teamwork), dan selalu berpikiran positif. 
Ada beberapa hal yang perlu diperhatikan agar dapat berbicara dengan sopan dan berkomunikasi dengan baik menurut Pranowo (2012), antara lain: (1) Bahasa sopan mampu menggunakan bahasa verbal (bahasa tertulis) dan bahasa non verbal juga dapat dibantu dengan bahasa lisan, (2) Bahasa sopan tidak musti menggunakan bahasa baku, namun harus digunakan sesuai dengan aturan bahasa yang baik. (3) Gunakan gaya sopan atau "santun" (mis: mohon, mohon, minta maaf). (4) Bicarakan tentang topik yang dipahami dan diperhatikan oleh lawan bicara. (5) Membuat mitra bicara tertarik dengan pidato pembicara sehingga mereka dapat dengan mudah memahami makna pidato. (6) Mengidentifikasi pasangan bicara dengan betul, terlebih yang terkait identitas dan kesenangan pribadi. (7) Ciptakan konteks dengan menguntungkan bagi lawan wicara sehingga perhatian lawan wicara fokus pada pembicara. Dengan demikian kebiasaan berbicara dengan baik dan sopan akan berimplikasi pada pembentukan kepribadian seseorang.

Bahasa positif dapat digunakan dengan melakukan hal-hal seperti: 1) memikirkan beberapa pilihan bahasa / kata yang tepat untuk anak, 2) menjawab sejumlah pertanyaan yang diajukan anak, 3) menyelaraskan dengan kata-kata yang dikutip, dan 4) menghindari kata "tidak" dan "tidak" dan "tidak". Mungkin tidak "dan" dilarang ". Dengan demikian, bahasa negatif tentunya bisa diubah dengan bahasa yang positif, seperti kalimat 'jangan mencoretcoret dinding!' diganti dengan 'menulislah di kertas saja saja!'. Dalam bahasa Melayu kata negatif "anak kurang ajar" sering dipositifkan dengan "anak bertuah".

Setiap orang tua ingin anaknya selalu menuruti apa yang dikatakan atau diperintahkan. Keengganan atau penolakan seorang anak untuk melakukan atau menaati apa yang dikatakan atau diperintahkan orang tua bukan karena anak itu malas atau tidak patuh. Anak-anak sering merasa bingung tentang apa yang harus dilakukan dengan perintah atau apa yang orang tua katakan. Untuk itu, orang tua hendaknya mengklarifikasi perintah atau keinginan kepada anaknya agar anak dapat memahami dan mengetahui apa yang diperintahkan oleh orang tuanya. Dengan menggunakan kata-kata positif, anak akan memahami perintah dan keinginan yang disampaikan oleh orang tua. Kata-kata "tidak harus, tidak juga harus" diganti dengan kata-kata "harus" atau "akan lebih baik".

Dari aspek anak, untuk mencegah dan menghindari kekerasan verbal dapat diupayakan melalui pendidikan ramah anak dalam keluarga dan metode pembelajaran berbasis karakter. Pendidikan ramah anak dalam keluarga dapat dilakukan melalui: 1) Melaksanakan komunikasi yang seimbang antara orang tua dan anak. 2) Menerapkan disiplin terhadap kekerasan; Dan 3) penerapan pembinaan kepribadian positif pada anak (Usman, 2020). Dengan memberikan pendidikan yang layak pada anak sejak usia dini, dapat secara konsisten menanamkan perilaku positif pada anak dalam kehidupannya. Sehingga lahirlah generasi ramah anak dalam dirinya dan juga memutus rantai kekerasan terhadap anak, karena pendidikan dengan kekerasan akan berdampak pada tahap perkembangan anak dan tahap kehidupan anak mulai dari remaja maupun dewasa.

Salah satu metode pembelajaran yang dapat menjadi sarana edukasi bagi anak adalah dengan menggunakan media lagu anak sebagai media preventif. Nyanyian anak adalah sarana pencerdasan menyenangkan untuk anak yang diisi dengan nilai-nilai karakter yang bisa dimengerti dan diterapkan oleh anak atau siswa (Widyaningrum, 2019). Prose belajar karakter akan semakin mencuri perhatian dengan menggunakan aransement yang populer serta gampang diingat oleh anak sehingga bisa memotivasi untuk menjadi pribadi yang lebih baik. Dengan demikian, aktivitas kurang baik misalnya bullying dan pelecehan verbal dapat dikurangi bahkan dihindari.

\section{SIMPULAN}

Faktor pengalaman dan pengetahuan orangtua merupakan faktor dominan orangtua yang melakukan kekerasan verbal terhadap anaknya. Dampaknya, anak menjadi manusia yang tidak berakhlak, baik dari segi perbuatan maupun ucapan. Anak mudah menggunakan bahasa-bahasa yang negatif dalam kehidupan sosialnya dan melakukan tindakan-tindakan 1622 | Jurnal Obsesi: Jurnal Pendidikan Anak Usia Dini, 5(2), 2021 
yang menyimpang. Upaya mencegah dan mengatasinya adalah dengan memositifkan bahasa dalam berkomunikasi terhadap anak. Disamping itu orangtua harus mampu menambah pengetahuan parenting, serta menghindari bahasa negatif serta bisa memilih kosa kata yang lebih baik untuk anak.

\section{DAFTAR PUSTAKA}

Alfianur, A., Ezalina, E., \& Fitriami, E. (2020). Kekerasan emosional menyebabkan kenakalan pada remaja. Holistik Jurnal Kesehatan, 14(1), 52-58. https://doi.org/10.33024/hjk.v14i1.2309

Armiyanti, I., Aini, K., \& Apriana, R. (2017). Pengalaman verbal abuse oleh keluarga pada anak usia sekolah di kota semarang. Jurnal Keperawatan Soedirman, 12(1), 12. https://doi.org/10.20884/1.jks.2017.12.1.714

Bakhtiar, A. (2014). Filsafat Ilmu. Raja Grafindo Persada.

Erniwati, E., \& Fitriani, W. (2020). Faktor-Faktor Penyebab Orang Tua Melakukan Kekerasan Verbal Pada Anak Usia Dini. Yaa Bunayya: Jurnal Pendidikan Anak Usia ..., 4197. https://jurnal.umj.ac.id/index.php/YaaBunayya/article/view/6680

Fajri, R. (2019). Psikolog Sebut Kekerasan Verbal Lebih Bahaya Ketimbang Fisik. Mediaindonesia.Com. https://mediaindonesia.com/read/detail/228624-psikologsebut-kekerasan-verbal-lebih-bahaya-ketimbang-fisik

Farhan, Zahara. (2018). Faktor-Faktor yang Melatarbelakangi Orang Tua Melakukan Verbal Abuse pada Anak Usia Sekolah 6-12 Tahun di Kabupaten Garut. JKM, 3(2).

Farhan, Zahra. (2019). Verbal abuse, anak,orang tua faktor-faktor yang melatarbelakangi orang tua melakukan verbal abuse pada anak usia sekolah 6-12 tahun di kabupaten garut. Jurnal Keperawatan Malang, 3(2), 101-108. https:// doi.org/10.36916/jkm.v3i2.70

Fitriana, Y., Pratiwi, K., \& Sutanto, A. V. (2015). Faktor-faktor yang berhubungan dengan perilaku orang tua dalam melakukan kekerasan verbal terhadap anak usia pra-sekolah. Jurnal Psikologi Undip, 14(1). https:/ / doi.org/10.14710/jpu.14.1.81-93

Irwanto. (1997). Psikologi umum. Buku penduan mahasiswa. 47.

Kadir, A., \& Handayaningsih, A. (2020). Kekerasan Anak dalam Keluarga. WACANA, 12(2), 133-145. https://doi.org/10.13057/wacana.v12i2.172

Khahtibah, K. (2013). Pengembangan Perpustakaan sebagai Pusat Sumber Belajar dalam Kegiatan Instruksional pada IAIN-SU Medan. Jurnal Perpustakaan dan Informasi, 5(1), 36-39.

Lestary, T. (2016). Verbal Abuse Dampak buruk dan Solusi Penanganannya pada Anak. 17-80.

Mahmud, B. (2019). Kekerasan verbal pada anak. Jurnal An Nisa', 12(2), 689-694.

Munawati. (2011). Hubungan Verbal Abuse dengan Perkembangan Kognitif pada Anak Usia Prasekolah di RW 04 Kelurahan Rangkapan Jaya Baru Depok.

Mustillo, S. A., Budd, K., \& Hendrix, K. (2013). Obesity, Labeling, and Psychological Distress in Late-Childhood and Adolescent Black and White Girls: The Distal Effects of Stigma. Social Psychology Quarterly, 76(3), 268-289. https://doi.org/10.1177/0190272513495883

Mysa, A. Y., \& Fithria. (2016). Pengetahuan orangtua tentang kekerasan verbal pada anak pra sekolah di Aceh. Jurnal Ilmiah Mahasiswa Fakultas Keperawatan, 1(1).

Narwoko, J. D., \& Suyanto, B. (2006). Sosiologi Teks Pengantar dan Terapan. Sosiologi Teks Pengantar dan Terapan, 74-96.

Neil J. Salkind. (2002). Child development. Choice Reviews Online, 39(11), 39-6171-39-6171. https:/ / doi.org/10.5860/choice.39-6171

Nurjamal, D., Sumirat, W., \& Darwis, R. (2011). Terampil berbahasa. Bandung: Alfabeta.

Nurwijayanti, A. M., \& Iqomh, M. K. B. (2019). Hubungan Antara Usia dan Pendidikan dengan Perilaku Verbal Abuse oleh Keluarga. Jurnal Keperawatan Jiwa, 7(3), 337. https://doi.org/10.26714/jkj.7.3.2019.337-342

Pranowo. (2012). Berbahasa Secara Santun.

Putri, A., \& Santoso, A. (2012). Persepsi orang tua tentang kekerasan verbal pada anak. 
Diponegoro Journal of Nursing, 1(1), 22-29.

Riniwati. (2015). Mari Mencintai Bahasa Indonesia. Transformatika, 11(10), 139-148. https:// doi.org/10.31002/transformatika.v11i1.117

Saudah, S. (2014). Bahasa Positf Sebagai Sarana Pengembangan Pendidikan Moral Anak. AlUlum, 14(1), 67-84.

Siregar, L. Y. S. (2017). Pendidikan anak dalam islam. Bunayya, 1(2), 16-32.

Soetjiningsih. (2014). Tumbuh Kembang Anak.

Strub, P. J., Rubington, E., \& Weinberg, M. S. (1979). Deviance: The Interactionist Perspective. Contemporary Sociology, 8(1), 73. https://doi.org/10.2307/2064907

Tarabulsy, G. M., Pascuzzo, K., Moss, E., St-Laurent, D., Bernier, A., Cyr, C., \& DuboisComtois, K. (2008). Attachment-Based Intervention for Maltreating Families. American Journal of Orthopsychiatry, 78(3), 322-332. https://doi.org/10.1037/a0014070

Vega, A. De, Hapidin, H., \& Karnadi, K. (2019). Pengaruh Pola Asuh dan Kekerasan Verbal terhadap Kepercayaan Diri (Self-Confidence). Jurnal Obsesi : Jurnal Pendidikan Anak Usia Dini, 3(2), 433. https://doi.org/10.31004/obsesi.v3i2.227

Wibowo, F., \& Parancika, R. B. (2020). Kekerasan Verbal ( Verbal Abuse ) Di Era Digital Sebagai Faktor. Prosiding Semnas Kbsp V Pembahasan, May.

Widiharto, C. A., Suhendri, S., \& Venty, V. (2012). Penyuluhan Perkembangan Anak Usia Dini dan Anak Hyperactive Kecamatan Godong Kabupaten Grobogan. E-Dimas: Jurnal Pengabdian kepada Masyarakat, 3(2), 30-34.

Widyaningrum, A. (2019). Lagu anak sebagai preventif perilaku bullying. Malih Peddas $\begin{array}{lllll}\text { (Majalah Ilmiah } & \text { Pendidikan }\end{array}$ https:// doi.org/10.26877/malihpeddas.v8i2.3668

Winarni, R., Slamet, S. Y., \& Saddhono, K. (2018). Development of Indonesian literature textbook with character education through information and communication technology (ICT) learning based. International Journal of Engineering and Technology(UAE), $7(2.13 \quad$ Special Issue 13$), \quad 442-446$. https://doi.org/10.14419/ijet.v7i3.2.14568

Wong, D. . (2008). Buku Ajar Keperawatan Pediatrik Wong. EGC.

Wulandari, V., \& Nurwati, N. (2018). Hubungan Kekerasan Emosional Yang Dilakukan Oleh Orangtua Terhadap Perilaku Remaja. Prosiding Penelitian dan Pengabdian kepada Masyarakat, 5(2), 132. https://doi.org/10.24198/jppm.v5i2.18364

Zuhrudin, A. (2017). Reformulasi Bahasa Santun Sebagai Upaya Melawan Kekerasan Verbal Terhadap Anak. Sawwa: Jurnal Studi Gender, 12(2), 265. https:// doi.org/10.21580/sa.v12i2.1706 